\title{
Electrification of the Paris-Orleans and Midi Railways
}

$\mathrm{T}$ HE paper read on November 18 by $\mathrm{Mr}$. A. Bachellery at a joint meeting of the Institution of Electrical Engineers with the British Section of the French Society of Civil Engineers, shows that considerable progress has been made with the electrification of some of the French railways since Mr. Bachellery read a previous paper in 1923. At that date, only about 15 miles of the Paris-Orléans railway was operated electrically, and on the Midi railway there were three sections operating on different systems and at different pressures.

In 1934 the two railway systems were formed into a single group, the electrification work being under common direction. The new permanent way equipments are now of the 1,500 volt direct current type. The system covers nearly the whole of the mountain lines in the Pyrenees, including the two trans. Pyrenean routes, where there are gradients of more than 1 in 25. Next year, when the line between Tours and Bordeaux has been completed, electric locomotives will be able to run without interruption from Paris to Irun on the Spanish frontier, a distance of about 500 miles. At present electrification covers 22 per cent of the length of the whole system and handles 50 per cent of the traffic.

In 1936 the consumption of electrical energy for the railways was 470 million kilowatt hours, and this effected a considerable economy in the use of coal. The energy is mainly produced by hydro-electric plants belonging to the railways, but part is drawn from steam plants connected with the railways' highvoltage lines.

In some parts of the line it was necessary to adopt electrification, as with coal the attainable speed and maximum loads were far too low. It is noteworthy thatalthough the companies have made very successful attempts to improve the power and fuel economy of its express steam locomotives, the electrification still makes steady progress in advance.

The weight of the fast passenger trains on the French railways is going steadily up. They now often weigh about 750 tons. This is due to the continued increase in the construction of metal coaches and the growing demand for comfort. The road transport competition has forced them to raise their speed, and this implies a large increase in tractive power. Whilst the continuous rating of the most modern passenger steam locomotives does not in practice exceed 2,500 h.p. at the drawbar, and it is only with great difficulty that the average fireman can with stand the strain that this represents, the performance of the high-speed electric locomotive is at least 50 per cent greater. This easily gives the required acceleration for heavy passenger trains.

The average economy of coal on the companies' electrified lines is roughly 670 metric tons per mile of route, and this warrants the cost of electrically equipping the permanent way. Recent economic and social changes have tended to increase operating expenses; but this increase is far less in the case of electric traction than with steam traction. This is due to the fact that whilst the price of coal is steadily rising, that of the energy generated in the companies' water-power plants is practically constant. The capital spent on electrification by the Paris-Orléan. and Midi companies has proved a good investment.

\section{Drilling Mud}

$\mathrm{M}$ UD-FLUID is now an important factor in oil field development, but although it has actually been in use for more than sixty years, comparatively little technical literature is available on the subject. P. Evans and A. Reid, being sensible of this position, and particularly of the essential part now played by mud-fluid in rotary drilling, have compiled a paper (Trans. Min. and Geol.'Inst. India, 32, December 1936) which has for its theme the investigation of the properties of mud-fluid, its manufacture and testing.

In this paper, which forms a complete volume, are incorporated certain results of experimental work carried out in the Burmah Oil Company's laboratories and also a review of literature consulted by that Company's technical staff during the course of research work.

Mud-fluid is best prepared by the combined methods of jetting and churning, and should be manufactured at a central plant to facilitate distribution where there are many rotary wells. Reconditioning of used mud by means of de-gassing and de-sanding is essential, especially where the cost of new mud is high; this can sometimes be done by chemical methods, though mechanical means are more usually employed. Above all, mud-fluid should be adequately and regularly tested. Specific gravity can be controlled by varying the proportions of solid and liquid. Viscosity should be determined, and in so doing both 'yield value' and 'mobility' taken into consideration, as the flow of drilling mud is not similar to that of a simple liquid such as water. Specially designed viscometers are suggested for determination of this function. As the mud has to flow at high speed in a very restricted space, the pressure needed to pump it through the circulating system of the well is proportionately high, and lines are indicated on which it might be possible to relate physical properties of the mud to pressures required for pumping them.

Thixotropy has also to be taken into account in assessing the value and efficiency of mud-fluid. This is a property which causes certain muds to set to a jelly-like mass, but to return to a mobile liquid when agitated. The change from liquid to jelly and vice versa may be repeated almost indefinitely. Viscosity measurement of thixotropic substances is complicated, as viscosity increases or decreases according to whether the mud is agitated or disturbed.

Various other properties of mud-fluid are discussed and the whole work liberally illustrated by graphical and other results. The book serves admirably to show the present state of knowledge of this somewhat obscure subject, and to indicate the lines on which future research could most profitably be undertaken. 